\title{
Spontaneous Reversal of Acquired Autoimmune Dysfibrinogenemia Probably Due to an Antiidiotypic Antibody Directed to an Interspecies Cross-reactive Idiotype Expressed on Antifibrinogen Antibodies
}

\author{
Alejandro Ruiz-Arguelles \\ Department of Immunology, Laboratorios Clinicos de Puebla, Puebla, Puebla 72530, Mexico
}

\begin{abstract}
A young man with a long history of abnormal bleeding was seen in January 1985. Coagulation tests showed dysfibrinogenemia and an antifibrinogen autoantibody was demonstrable in his serum. This antibody, when purified, was capable of inhibiting the polymerization of normal fibrin monomers, apparently through binding to the $\alpha$ fibrinogen chain. 6 mo later the patient was asymptomatic, coagulation tests were normal, and the antifibrinogen autoantibody was barely detectable. At this time, affinity-purified autologous and rabbit antifibrinogen antibodies were capable of absorbing an IgG kappa antibody from the patient's serum, which reacted indistinctly with both autologous and xenogeneic antifibrinogen antibodies in enzyme immunoassays. It has been concluded that the patient's dysfbrinogenemia was the result of an antifibrinogen autoantibody, and that later on an antiidiotype antibody, which binds an interspecies cross-reactive idiotype expressed on anti-human fibrinogen antibodies, inhibited the production of the antifibrinogen autoantibody which led to the remission of the disorder.
\end{abstract}

\section{Introduction}

The presence of auto anti-Id antibodies, directed towards Ids expressed on antibodies against exogenous (1-3) as well as endogenous (4-8) antigens, has been widely documented in humans. In fact, it is presumable that the expression of autoimmune humoral immune responses might be modulated, ita, est, augmented, or depressed, by anti-Id antibodies (6, 9-11). The production of autoantibodies directed to fibrinogen as a cause of dysfibrinogenemia has been observed in the past (12-15). In some instances, these antibodies interfere with fibrinogen clotting by inhibiting the cleavage of fibrinopeptides A and B by thrombin, while in other instances they block the polymerization of fibrin monomers after thrombin cleavage.

This report refers to a case of autoimmune dysfibrinogenemia that was due to an antibody that inhibited fibrin polymerization, in which a spontaneously produced anti-Id autoantibody caused the inhibition of the antifibrinogen autoantibody and led to the clinical remission of the hemorrhagic

Address all correspondence to Dr. Alejandro Ruiz-Arguelles, Laboratorios Clinicos de Puebla, Diaz Ordaz 808, Puebla, Pue. 72530, Mexico.

Received for publication 25 August 1987 and in revised form 18 April 1988.

J. Clin. Invest.

(C) The American Society for Clinical Investigation, Inc. 0021-9738/88/09/0958/06 \$2.00

Volume 82, September 1988, 958-963 disorder. This anti-Id antibody was shown to react with xenogeneic antifibrinogen antibodies, hence, its specificity is an interspecies cross-reactive Id (IdX) ${ }^{1}$ most likely encoded by germline V-region genes.

\section{Methods}

Case report. A 22-yr-old male patient with a long history of abnormal bleeding was referred to Laboratorios Clinicos de Puebla in January 1985. For $10 \mathrm{yr}$ he had presented a moderate to severe bleeding tendency characterized by recurrent bleeding for several days from lacerations or dental procedures, soft tissue hematoma formation after mild trauma, and one episode of intraarticular bleeding. He had no family history of bleeding disorders or autoimmune diseases. Although he was seen by several physicians, a definite diagnosis of his hemostatic abnormality was never established. When first studied in our clinic he had abnormally prolonged thrombin and reptilase times $(16,17)$, while the clottable fibrinogen was $<10 \%$ of the total fibrinogen mass as detected by immunological and thermoprecipitation methods (18). Reptilaseinduced fibrin polymerization (17) was null. Complete hemostatic test results are summarized in Table I. The physical examination revealed retinal vasculitis, and cryoglobulins were demonstrated in his serum. The diagnosis of dysfibrinogenemia of possible autoimmune origin was established. Other laboratory tests for autoimmunity, such as lupus erythematosus clot, antinuclear antibodies, antiplatelet antibodies, direct antiglobulin test, Ig levels, and rheumatoid factor, were all normal or negative. A 10-d course of low-dose methylprednisolone was given and withdrawn gradually in 2 wk. 6 mo later, he was absolutely asymptomatic and all the laboratory tests had returned to normal. He has been in complete remission for $30 \mathrm{mo}$.

Demonstration, isolation, and characterization of the autoantifibrinogen antibody. Detection of antifibrinogen antibodies was performed by means of an enzyme-linked immunosorbent assay (19). Briefly, purified human fibrinogen (lot S4F-9545, Sigma Chemical Co., St. Louis, MO) was adsorbed to microtiter dishes (Nunc, Roskilde, Denmark) by overnight incubation in carbonate buffer. Serum samples and controls were placed in triplicate wells and incubated for 2 h. After washing the wells repeatedly, an alkaline phosphatase-labeled goat anti-human Ig antibody (lot 123F-8860; Sigma) was added and its binding was demonstrated by the addition of $p$-nitrophenyl-phosphate. Antifibrinogen antibodies were purified by affinity chromatography on columns containing purified human fibrinogen coupled to cyanogen bromide ( $\mathrm{CNBr}$ )-activated Sepharose 4B beads (20). The chain specificity of the antifibrinogen antibody was analyzed by immunoblotting (21); native purified fibrinogen, as well as samples that were either reduced by 2 -mercaptoethanol (2ME) (22) or cleaved by $\mathrm{CNBr}(23)$ were electrophoresed onto $7.5 \%$ polyacrylamide gels and transferred to nitrocellulose sheets. Duplicate strips, each of which contained the three different fibrinogen preparations, were reacted with the patient's antifibrinogen antibody; and its binding was developed by using a biotinylated anti-human IgG antibody (lot 60407; Vector Laborato-

1. Abbreviations used in this paper: $\mathrm{CNBr}$, cyanogen bromide; EIA, enzyme immunoassay; IdX, cross-reactive Id; 2ME, 2-mercaptoethanol. 
Table I. Coagulation Studies in the Patient When Symptomatic and during Clinical Remission

\begin{tabular}{|c|c|c|c|}
\hline \multirow[b]{2}{*}{ Test } & \multicolumn{3}{|c|}{ Result } \\
\hline & Symptomatic & Remission & $\begin{array}{l}\text { Normal or } \\
\text { control }\end{array}$ \\
\hline \multicolumn{4}{|l|}{ Fibrinogen (immunodiffusion) } \\
\hline$(m g / d l)$ & 206 & 270 & $200-500$ \\
\hline Fibrinogen (clottable) $(m g / d l)$ & 18 & 240 & $200-400$ \\
\hline \multicolumn{4}{|l|}{ Thrombin time (s) } \\
\hline $25 N I H U$ & 278 & 79 & 82 \\
\hline $50 \mathrm{NIHU}$ & 68 & 33 & 36 \\
\hline Reptilase time (s) & $>300$ & 20 & 20 \\
\hline One-stage prothrombin time (s) & 47 & 32 & 34 \\
\hline Factor $\mathrm{V}$ activity & Normal & Normal & Normal \\
\hline Factor VIII activity & Normal & Normal & Normal \\
\hline Factor VIII related antigen (\%) & 96 & 102 & $65-130$ \\
\hline \multicolumn{4}{|l|}{ Platelet aggregation (\%) } \\
\hline \multicolumn{4}{|l|}{ Adenosine diphosphate } \\
\hline$(1 \mathrm{mg} / \mathrm{ml})$ & 86 & 96 & $>78$ \\
\hline Epinephrine $(3 \mathrm{mg} / \mathrm{ml})$ & 22 & 90 & $>85$ \\
\hline Collagen $(1.68 \mathrm{mg} / \mathrm{ml})$ & 70 & 88 & $>83$ \\
\hline Ristocetin $(20 \mathrm{mg} / \mathrm{ml})$ & 100 & 100 & $>82$ \\
\hline D dimers & Negative & Negative & Negative \\
\hline
\end{tabular}

ries Inc., Burlingame, $\mathrm{CA}$ ) and avidin-peroxidase conjugates (lot 60423; Vector Laboratories).

The heavy and light chain classes of the affinity-purified autoantifibrinogen antibody were determined by immunofixation with antisera to gamma, alpha, mu, kappa, and lambda chains (lots 25086, 24599, 20102, 24849, and 17811; Cappel Laboratories, Malvern, PA) after high-voltage agarose-gel electrophoresis $(24,25)$. Briefly, electrophoresis was performed in $0.9 \%$ agarose gels (lot 101F-0183; Sigma) in barbital buffer $\mathrm{pH} 8.6$, ionic strength 0.05 . Gels were placed in a precooled flat-bed electrophoresis chamber (Multiphor; LKB Instruments, Inc., Gaithersburg, MD) and after sample application, a constant voltage of $20 \mathrm{~V} \mathrm{~cm}^{-1}$ was applied for $15 \mathrm{~min}$. Gels were placed in a humid chamber and each lane was covered with acetate cellulose strips that had been previously soaked in the different antisera. After a 1-h incubation, the strips were removed and the gels were washed in $0.15 \mathrm{M}$ $\mathrm{NaCl}$ for $48 \mathrm{~h}$ before drying them and staining the precipitated proteins with Coomassie Brilliant Blue dye (lot 11128; LKB Instruments).

Determination of the functional effects of the autoantifibrinogen antibody. This was achieved by preincubating purified normal human fibrinogen $(0.6 \mathrm{~g} /$ liter in $0.15 \mathrm{M} \mathrm{NaCl})$ with either $5 \%$ (vol/vol) normal serum, $5 \%$ (vol/vol) patient's serum, normal human IgG at a final concentration of $110 \mu \mathrm{g} / \mathrm{ml}$, or the affinity-purified antifibrinogen autoantibody at the same final concentration. Since preliminary experiments showed that the effect of the affinity-purified antibody upon polymerization was not different from that caused by whole serum, the vast majority of these experiments were performed using serum samples. After 30-min incubations of the aforementioned mixtures, fibrin-monomer aggregation was induced either with reptilase (17), thrombin (26), or sequential reptilase-thrombin as described by Hensechen et al. (18). Detection of polymerization was done by laser nephelometry as previously reported (17). To assess the effect of the antifibrinogen antibody on the association of fibrin monomers after the fibrinopeptide cleavage step, monomers were prepared from purified fibrinogen in acetic acid and their aggregation was induced by neutralizing the medium (26) after the addition of serum samples or Igs as described above. To further confirm preliminary results, normal fibrinogen was treated with thrombin in the presence of either patient's or control serum samples according to Kehl et al. (27). After heat precipitation of fibrin (ogen), the supernatant was analyzed by hydrophobic interaction HPLC using a TSK phenyl 5 PW column (2133510; LKB, Bromma Sweden) along with a sodium sulfate gradient as described by Regnier and Fausnaugh (28). Additionally, total fibrinopeptide release was measured through quantitating the guanidino group of arginine according to Crum et al. (29).

Demonstration and isolation of anti-Id antibodies. The affinity-purified anti-human fibrinogen antibody isolated from the patient's serum was coupled to $\mathrm{CnBr}$-activated Sepharose and packed into columns. Domestically raised rabbit anti-human fibrinogen antibodies were also affinity-purified and coupled to Sepharose beads for chromatography. Serum samples from the patient when in clinical remission and from healthy controls were loaded into the aforementioned columns and allowed to react for $1 \mathrm{~h}$ at neutral $\mathrm{pH}$. After complete elution of the unbound material, the $\mathrm{pH}$ of the eluent was gradually lowered until all bound antibodies were obtained (20). The Ig heavy and light chain classes present in this material were analyzed by immunofixation as previously described, and their antibody specificity was assessed by enzyme immunoassay (EIA) in microtiter dishes coated with either autologous or xenogeneic affinity-purified anti-human fibrinogen antibodies. Control plates were coated with $10 \mu \mathrm{g} / \mathrm{ml}$ purified human IgG from different sources. These included five healthy young individuals, three patients with systemic lupus erythematosus, two patients with mixed connective tissue disease, and two patients with IgG Kappa multiple myeloma.

The anti-Id antibody molecules, bound from the patient's serum by the autologous antifibrinogen antibody column, were added in various concentrations to the purified autologous antifibrinogen antibody before testing the effect of the latter on the reptilase-induced aggregation of normal fibrin monomers as described above.

\section{Results}

Characteristics of the antifibrinogen autoantibody. As shown in Fig. 1, several serum samples of the patient taken when he was symptomatic, showed a concentration-dependent binding of Ig to purified fibrinogen. During remission, however, serum antifibrinogen antibodies were barely detectable. In no instance was binding of Igs from normal sera demonstrated. When samples containing antifibrinogen antibodies were passed through the insoluble fibrinogen columns, a single peak was eluted at $\mathrm{pH}$ 4.0. This peak consisted of gamma and lambda chains only and is seen as a very narrow band in the immunofixation experiments (Fig. 2), which suggests a monoclonal origin.

When the affinity-purified antifibrinogen antibody was assayed by immunoblotting, it was found to bind to a $350-\mathrm{kD}$

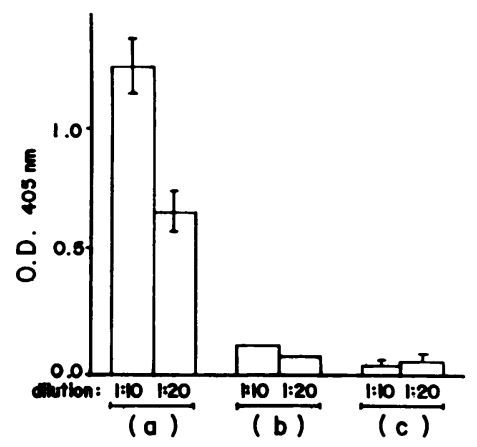

Figure 1. EIA demonstration of fibrinogen-binding antibodies in $(a)$ patient's serum samples that were taken when he was symptomatic (mean \pm SD of three samples), (b) a patient's sample taken when he was in clinical remission, and (c) five normal serum samples (mean $\pm \mathrm{SD}$ ). 


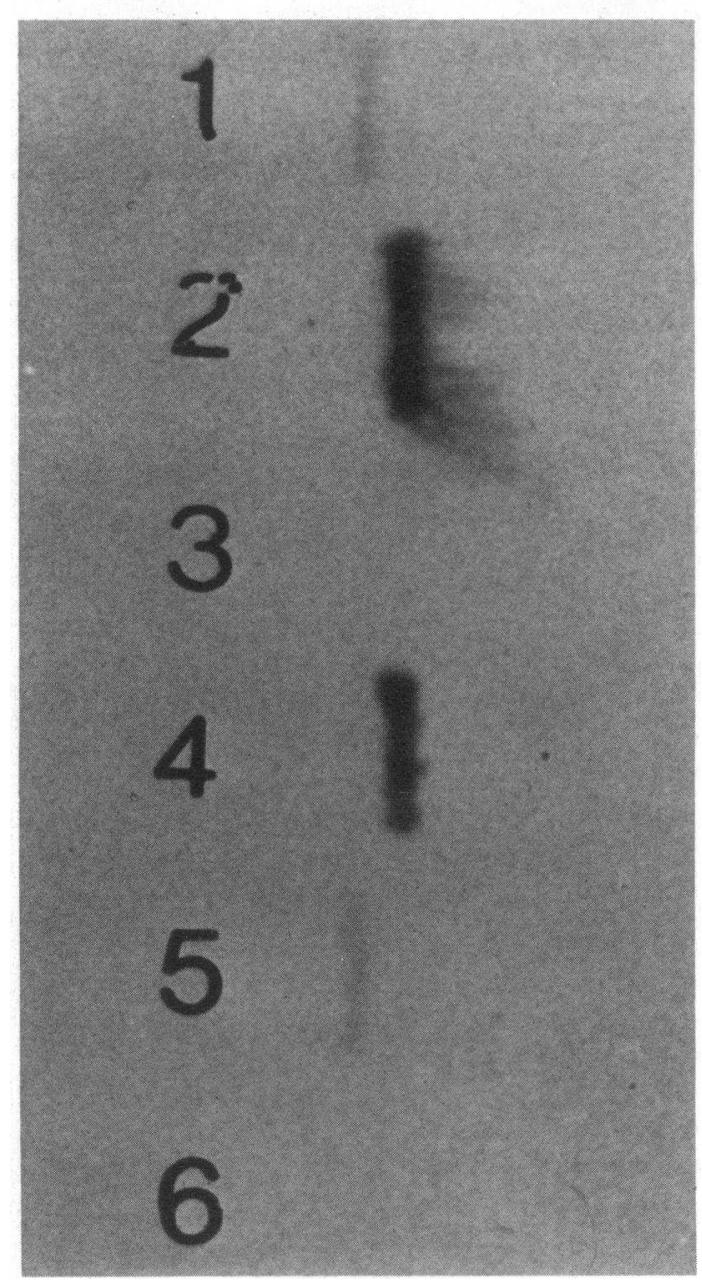

Figure 2. Immunofixation of affinity-purified antibodies after highvoltage agarose-gel electrophoresis. Lanes 1,3 , and 5 correspond to the antifibrinogen autoantibody eluted from Sepharose-fibrinogen columns (65 $\mu \mathrm{g} / \mathrm{ml}$ per lane). Lanes 2,4 , and 6 correspond to the patient's antibody eluted from the rabbit antifibrinogen antibody column $(200 \mu \mathrm{g} / \mathrm{ml}$ per lane). Lanes 1 and 2 were precipitated with an anti-human IgG (heavy chain-specific) antibody, lanes 3 and 4 with an anti-human kappa light chain antibody, and lanes 5 and 6 with an antibody specific for human lambda light chains.

band in the strips in which native fibrinogen was electrophoresed, to a $65-\mathrm{kD}$ band in which $2 \mathrm{ME}$-reduced fibrinogen was used, and to a 32-kD component when fibrinogen was cleaved with $\mathrm{CNBr}$ before electrophoresis (Fig. 3). In no instance was binding of normal sera to either preparation observed. These results strongly suggest that the autoantibody binds selectively to an antigenic determinant on the fibrinogen $\alpha$ chain which is available on native fibrinogen as well. Of the several fragments obtained from the $\alpha$ fibrinogen chain after $\mathrm{CNBr}$ cleavage, the Hi2-DSK fragment, which is hydrophilic and has an approximate molecular mass of $30 \mathrm{kD}$, is known to bear an antigenic determinant that is available in both isolated $\alpha$ chains and native fibrinogen (30). Taken altogether these data appear to indicate that the patient's autoantibody reacted with an antigenic determinant present in the Hi2-DSK fragment of the $\alpha$ chain of fibrinogen.

Fig. 4 depicts the results of the experiments in which the antifibrinogen autoantibody-containing serum was added to

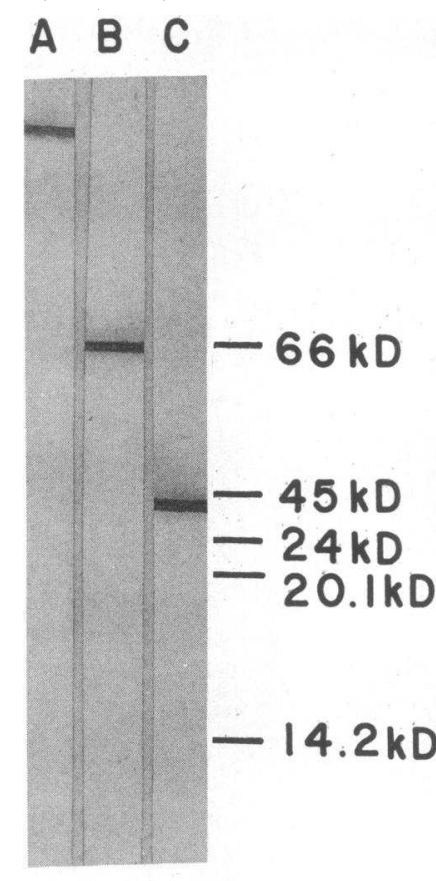

Figure 3. Western blot analysis of the specificity of the antifibrinogen autoantibody. Nonreduced $(A), 2 \mathrm{ME}-$ reduced $(B)$, and $\mathrm{CNBr}$-cleaved $(C)$ purified human fibrinogen samples were electrophoresed in a 7.5 polyacrylamide gel and then transferred electrophoretically to nitrocellulose. Strips were incubated with the purified antifibrinogen autoantibody and the reaction was developed with a biotinylated antihuman polyvalent Ig antibody. Numbers indicate approximate molecular weights. The results show the reactivity of the antibody with native fibrinogen

(lane $A$ ), fibrinogen $\mathrm{A} \alpha$ chain (lane $B$ ) and the Hi2-DSK $\mathrm{CNBr}$ fragment of the molecule (lane $C$ ).

functional fibrinogen assays. The results indicate that the inhibition of fibrin polymerization was not due to interference with fibrinopeptide cleavage by thrombin and/or reptilase, because when this stage was bypassed by thrombin cleavage before the addition of the antibody, the degree of inhibition of polymerization was not different. Moreover, when purified fibrinogen was cleaved by thrombin, the chromatographic pattern of the material released in the presence of the patient's and the normal subjects' serum samples was identical (Fig. 5), and the amount of total arginine released in both circumstances was similar, $(9.4 \pm 0.8$ and $9.7 \pm 0.9 \mathrm{nmol} / \mathrm{mg}$ fibrinogen, respectively), which confirms that the antifibrinogen autoantibody did not interfere with fibrinopeptide cleavage.
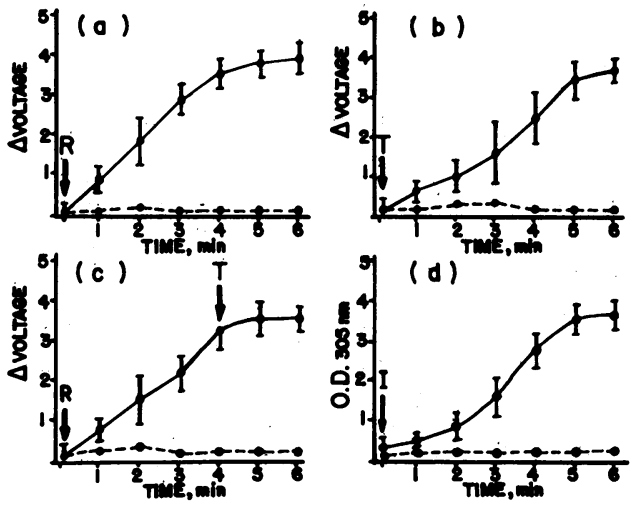

Figure 4. Effect of the addition of 5\% of the patient's serum taken when he was symptomatic (---) or of sera from five normal donors $(-)$ to fribrin polymerization assays. The figure shows the total inhibition of reptilase- $(R)(a)$, thrombin- $(T)(b)$, and reptilase-thrombin- $(c)$ induced fibrin polymerization caused by the patient's serum. $d$ shows the effect of patient's serum on the aggregation of fibrin monomers after fibrinopeptide cleavage. (I) The pH-dependent induction of aggregation. 


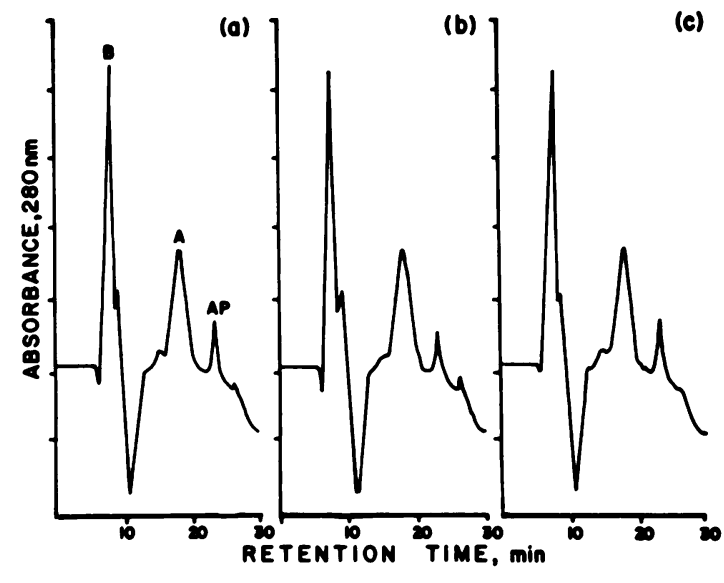

Figure 5. Hydrophobic interaction HPLC of material released after thrombin cleavage of purified human fibrinogen in the abscence of serum $(a)$, in the presence of a normal serum sample ( $5 \% \mathrm{vol} / \mathrm{vol})$ (b), and of a patient's serum sample taken when he was symptomatic $(5 \%)(c)$. Absorbance units full scale was 0.5. The initials in $a$ indicate the different fibrinopeptides that are discriminated by this method $25 \mathrm{~min}$ after the addition of 1.5 National Institutes of Health (NIH) thrombin $\mathrm{U} / \mathrm{mg}$ of fibrinogen.

Characteristics of the anti-Id antibody. Both autologous antifibrinogen antibody as well as rabbit anti-human fibrinogen antibody columns were capable of absorbing significant amounts of Ig from serum samples taken from the patient when he was in clinical remission but not from normal serum. Immunofixation experiments showed that the material eluted from both columns was formed exclusively of gamma and kappa chains. As shown in Fig. 2, the precipitate consisted of a narrow band, again suggesting the monoclonal nature of these antibodies. EIAs revealed that the antibody eluted from the autologous antifibrinogen antibody column reacted to a very similar degree with both autologous and xenogeneic antifibrinogen antibodies. On the other hand, antibody absorbed by xenogeneic antifibrinogen antibodies also reacted with the two kinds of antibodies (autologous and xenogeneic). Purified IgG from serum samples taken from five healthy young subjects bound neither to the human nor to the rabbit antifibrinogen antibody-coated dishes (Fig. 6). The anti-Id antibodies eluted from both columns did not bind to any of the Igs used to coat the control dishes. To rule out the possibility that the binding of the anti-Id antibody to the antifibrinogen antibody-coated EIA plates was due to interaction through its Fc portion,

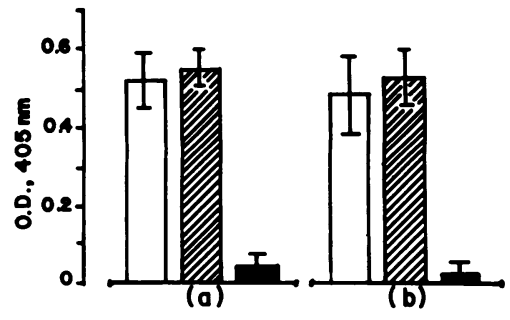

Figure 6. EIA in which the anti-Id antibody absorbed by the autologous antifibrinogen autoantibody (open bars) the anti-ID antibody absorbed by the xenogeneic antifibrinogen antibody (dashed bars), and purified IgG from five

healthy subjects (solid bars), were reacted with microtiter dishes coated with autologous $(a)$ and xenogeneic $(b)$ antifibrinogen antibodies. The bars represent the mean \pm SD of quadruplicate wells.

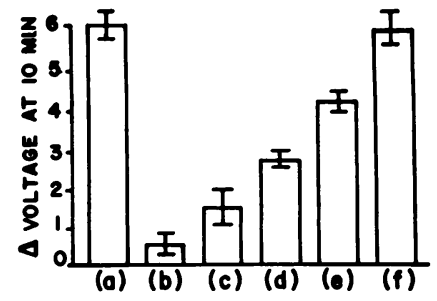

Figure 7. The aggregation of $600 \mu \mathrm{g} / \mathrm{ml}$ purified fibrinogen that appeared after $10 \mathrm{~min}$ of induction by reptilase $(a)$, was abrogated by preincubation (30 min at room temperature) with $100 \mu \mathrm{g} / \mathrm{ml}$ of the affinity purified antifibrinogen antibody (6). The addition, in the preincubation step, of $50(c), 100(d)$, and $200(e) \mathrm{mg} / \mathrm{ml}$ of the affinity-purified autologous anti-Id antibody gradually reverted the abrogating effect of the antifibrinogen antibody. The preincubation of purified fibrinogen with $200 \mu \mathrm{g} / \mathrm{ml}$ of the anti-Id antibody $(f)$ did not affect the aggregation process.

$\mathrm{F}\left(\mathrm{ab}^{\prime}\right)_{2}$ fragments of the anti-Id antibody were prepared as described (31) and tested in the EIA system against both autologous and rabbit antifibrinogen antibodies. The binding of $\mathrm{F}\left(\mathrm{ab}^{\prime}\right)_{2}$ fragments was not different from that of the whole antibody molecule. Taken altogether, these results suggest that the antibodies eluted from both columns are in fact a single, perhaps monoclonal, antibody directed to a IdX expressed on anti-human fibrinogen antibodies.

As shown in Fig. 7, the inhibitory effect of the affinity-purified autologous antifibrinogen antibody on the aggregation of fibrin monomers after its induction with reptilase, was reverted by the anti-Id antibody, which was eluted from the autologous antifibrinogen column, in a dose-dependent fashion.

This anti-Id antibody has been present in the patient's serum throughout the duration of the clinical remission.

\section{Discussion}

The studies performed on this patient showed that an impairment of fibrinogen polymerization was responsible for his bleeding disorder. The demonstration of the existence of an autoantibody directed against fibrinogen, which was capable of inhibiting fibrin aggregation during the active phase of the hemorrhagic disease but not while the patient was in clinical remission, strongly suggests that the antifibrinogen autoantibody was the cause of the fibrinogen dysfunction. Other cases of autoimmune dysfibrinogenemia have been reported in the past (12-15). In some cases the antibody inhibited polymerization of fibrinogen through blocking the cleavage sites for thrombin, while in others the antibody inhibited the aggregation of fibrin monomers after thrombin cleavage. In the case reported herein, the antifibrinogen autoantibody neither interfered with the cleavage of fibrinopeptide $A$ by reptilase, nor with that of fibrinopeptides A and B by thrombin, but it blocked the aggregation process itself. Since the antigenic determinant for this possibly monoclonal antibody seems to be located in the Hi2-DSK fragment of the $\alpha$ fibrinogen chain, it is presumable that the binding of the autoantibody in this highly hydrophilic region interfered with the polymerization process.

The presence of an anti-Id antibody that reacted with, and reverted the effect of, the antifibrinogen autoantibody during the clinical remission, is highly suggestive of an inhibitory role upon the production of the autoantibody. Although it is not possible to rule out the possibility that the anti-Id antibody is 
not suppressing the synthesis of the autoantibody, but merely blocking its effect upon fibrinogen, it seems unlikely since, during the clinical remission, no evidence of immune complex disease has been found in the patient and because the antifibrinogen antibody has not been detected. The reason why this patient expressed an autoantibody towards fibrinogen, for apparently $10 \mathrm{yr}$, and spontaneously developed an anti-Id antibody which probably has suppressed the synthesis of the former, remains unexplained.

The fact that the anti-Id antibody reacted also with rabbit anti-human fibrinogen antibodies, indicates that the specificity of this anti-Id antibody is an interspecies IdX. Examples of interspecies IdX, such as the cGATIdX in rodents, and the presence of the T15IdX in phosphocholine-binding antibodies raised in both mice and hamsters (32), have been previously reported. Moreover, it has been observed that goat and sheep antibodies against human sickle cell hemoglobin also share a common Id called ValIdX (32). Therefore, the presence of IdX in nonhuman antibodies directed to human proteins has also been documented in the past.

The existence of interspecies IdX is thought to reveal the high degree of conservation of germline V-region genes through the evolution of mammalian species. These genes, as are other highly conserved genes, are believed to confer selective advantages for the species. In this context, and considering the presumable inhibitory role of the anti-IdX antibody on the expression of the autoantifibrinogen antibody in the case studied herein, one may speculate that antifibrinogen antibodies are normally present at the precursor cell level, but that their expression is down-regulated by the idiotypic network. The search for this antifibrinogen antibody IdX (FibIdX) in precursor cells, and that of antifibrinogen antibody IdX molecules in healthy mammals, might be useful in proving that the antifibrinogen antibody IdX in fact belongs in the silent repertoire. The finding that IdX on human autoantibodies are largely shared, e.g., the Wa and Po IdX on rheumatoid factors (33), supports the contention that at least some autoantibodies are encoded by germline genes and might well be silent in the healthy individual. However, the selective advantage of the conservation of these autoantibodies remains to be determined.

\section{Acknowledgments}

The author is indebted to Matilde Valls-de-Ruiz for her helpful criticisms and skilled technical assistance. The assistance of Miguel Presno-Bernal and Lilia Tellez is also acknowledged.

\section{References}

1. Geha, R. S. 1982. Presence of auto-anti-idiotypic antibody during the normal human immune response to tetanus toxoid antigen. $J$. Immunol. 129:139-144.

2. Geha, R. S., and M. Comunale. 1983. Regulation of immunoglobulin $\mathrm{E}$ antibody synthesis in man by antiidiotypic antibodies. $J$. Clin. Invest. 71:46-54.

3. Gelther, D., E. C. Franklin, and B. Frangione. 1980. Anti-idiotypic activity in the IgM fractions of mixed cryoglobulins. J. Immunol. 125:1530-1535.
4. Pasquali, J. L., A. Urlacher, and D. Storck. 1984. Idiotypic network: possible explanation of seronegativity in a patient with rheumatoid arthritis. Clin. Exp. Immunol. 55:281-286.

5. Takeuchi, T., O. Hosono, J. Koide, M. Homma, and T. Abe. 1985. Supression of rheumatoid factor synthesis by antiidiotypic antibody in rheumatoid arthritis patients with cross-reactive idiotypes. Arthritis Rheum. 28:873-881.

6. Abdou, M. I., H. Wall, H. B. Lindsley, J. F. Halsey, and T. Susuki. 1981. Network theory in autoimmunity. In vitro suppression of serum anti-DNA antibody binding to DNA by antiidiotypic antibody in systemic lupus erythematosus. J. Clin. Invest. 67:1297-1304.

7. Morgan, A. C., Jr., R. D. Rossen, and J. J. Twomay. 1979. Naturally occurring circulating immune complexes: normal human serum contains idiotype-anti-idiotype complexes dissociable by certain IgG anti-globulins. J. Immunol. 122:1672-1680.

8. Sultan, Y., P. Maisonneuve, M. D. Kazatchkine, and U. E. Nydeggar. 1984. Anti-idiotypic suppression of antiantibodies to Factor VIII (antihaemophilic factor) by high-dose intravenous gammaglobulin. Lancet. ii:765-768.

9. Urbain, J., C. Collignon, J. D. Franssen, B. Mariame, D. Loo, U. Vansanten, P. V. Walle, M. Wikler, and C. Wuilmart. 1979. Idiotypic networks and self-recognition in the immune system. Ann. Immunol. Inst. Pasteur. 130:281-287.

10. Talal, N. 1978. Autoimmunity and the immunologic network. Arthritis Rheum. 21:853-855.

11. Smith, C. I. E., and L. Hammarstrom. 1984. Selection of autoantibodies. Lancet. ii:932-933.

12. Hoots, W. K., N. A. Carrell, R. H. Wagner, H. A. Cooper, and J. McDonagh. 1981. A naturally occurring antibody that inhibits fibrin polymerization. N. Engl. J. Med. 304:857-861.

13. Rosemberg, R. D., R. W. Colman, and L. Lorand. 1974. A new haemorragic disorder with defective fibrin stabilization and cryofbrinogenemia. Br. J. Haematol. 26:269-284.

14. Marciniak, R., and M. F. Greenwood. 1979. Acquired coagulation inhibitor delaying fibrinopeptide release. Blood. 53:81-92.

15. Mammen, E. F., K. P. Schimidt, and M. I. Barnhart. 1967. Thrombophlebitis migrans associated with circulating antibodies against fibrinogen: a case report. Thromb. Diath. Haemorrh. 18:605611.

16. Jim, R. T. S. 1957. A study of the plasma thrombin time. J. Lab. Clin. Med. 50:45-60.

17. Ruiz-Arguelles, A., and B. Perez-Romano. 1986. Sensitive and rapid measurement of fibrin polymerization by laser nephelometry. $J$. Clin. Pathol. 39:227-229.

18. Hensechen, A., M. Kehl, and C. Southan. 1984. Genetically abnormal fibrinogens. Strategies for structure elucidation, including fibrinoeptide analysis. In Variants of Human Fibrinogen. E. A. Beck and M. Furlan, editors. Hans Huber Publishers, Toronto. 273-317.

19. Voller, A., D. Bidwell, G. Huldt, and E. Engvall. 1974. A microplate method of enzyme-linked immunosorbent assay and its application to malaria. Bull. W. H. O. 51:209-215.

20. Mannik, M., and D. E. Stage. 1971. Antibody-agarose immunoadsorbents: complete removal of classes of immunoglobulins from serum. J. Immunol. 106:1670-1677.

21. Towbin, H., T. Staehelin, and J. Gordon. 1979. Electrophoretic transfer of proteins from polyacrylamide gels to nitrocellulose sheets: procedure and some applications. Proc. Natl. Acad. Sci. USA. 76:4350-4354.

22. Stanworth, D. R., and M. W. Turner. 1978. Immunochemical analysis of immunoglobulins and their sub-units. In Handbook of Experimental Immunology. 3rd ed. D. M. Weir, editor. Blackwell Scientific Publications, Oxford. 6.1-6.102.

23. Blomback B., B. Hessel, S. Iwanga, J. Reuterby, and M. Blomback. 1972. Primary structure of human fibrinogen and fibrin. I. Cleavage of fibrinogen with cyanogen bromide. Isolated and characterization of NH2 terminal fragments of the (A) chain. J. Biol. Chem. 247:1496-1512. 
24. Ruiz-Reyes, G., N. Landero-de-Ruiz, and T. Armenta-Olvera. 1978. Immunoelectrocataphoresis: an immunoelectrophoresis variant to detect fibrinogen electrophoretic abnormalities. Rev. Invest. Clin. 30:337-341.

25. Alper, C. A., and A. M. Johnson. 1969. Immunofixation electrophoresis: a technic for the study of protein polymorphism. Vox Sang. 17:445-451.

26. Higgins, D. L., J. A. Penner, and J. A. Shafer. 1981. Fibrinogen Petoskey: identification of a new dysfibrinogenemia characterized by altered release of fibrinopeptide A. Thromb. Res. 23:491. (Abstr.)

27. Kehl, M., F. Lottspeich, and A. Henschen. 1981. Analysis of human fibrinopeptides by high performance liquid chromatography. Hoppe-Seyler's Z. Physiol. Chem. 362:1661-1664.

28. Regnier, M., and J. Fausnaugh. 1983. High performance hydrophobic interaction chromatography of proteins and polynucleotides. Liquid Chromatography. 1:402-406.
29. Crum, E. D., J. R. Shainoff, R. O. Graham, and O. D. Ratnoff. 1974. Fibrinogen Cleveland II. An abnormal fibrinogen with detective release of fibrinopeptide A. J. Clin. Invest. 53:1308-1319.

30. Gardlund, B., B. Hessel, G. Marguerie, G. Murano, and B. Blomback. 1977. Primary structure of human fibrinogen. Characterization of disulfide-containing cyanogen-bromide fragments. Eur. J. Biochem. 77:595-610.

31. Nisonoff, A., G. Markus, and F. C. Wissler. 1961. Separation of univalent fragments of rabbit antibody by reduction of a single, labile disulphide bond. Nature (Lond.). 189:293-296.

32. Bona, C. Idiotypes and Lymphocytes. 1981. Academic Press, New York. 1-37.

33. Posnett, D. N., R. Wisniewolski, B. Pernis, and H. G. Kunkel. 1986. Dissection of the human antigammaglobulin idiotype system with monoclonal antibodies. Scand. J. Immunol. 23:169-181. 